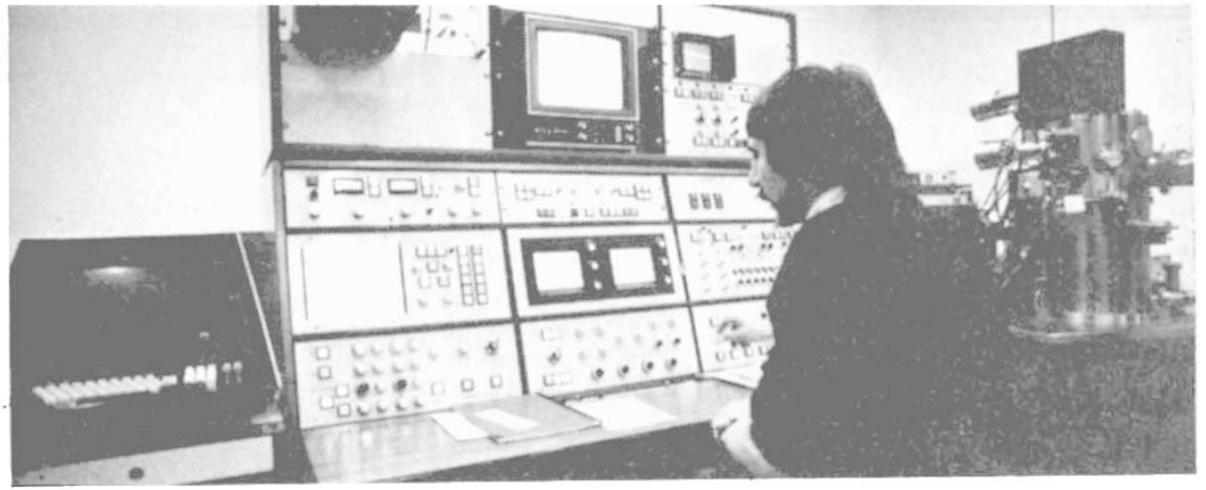

\title{
China encourages school science
}

Developments in China continue to reflect the new emphasis on education and science. At the end of April, a month after the science conference, the Chinese Ministry of Education organised a national conference on educational work. In the opening speech, Teng Hsiao-ping repeated Chairman Hua's call to train a mammoth contingent of working class intellectuals and to raise the scientific and cultural
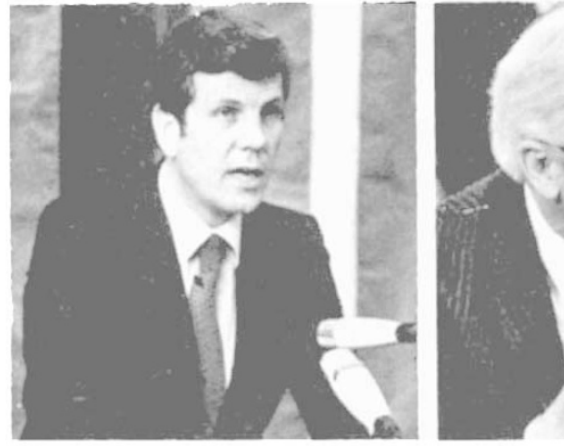

nations. He said it was also possible that instruments would be developed for commercial exploitation with royalties going to EMBL.

The other major feature of EMBL which may never be matched in Europe is its high containment recombinant DNA facility. This was added to the plans of EMBL in 1976 and is now nearing completion. It occupies a separate building of $700 \mathrm{~m}^{2}$, which consists of a series of normal open laboratories and offices separated from a series of high containment laboratories by a range of showers and autoclaves through which all personnel and equipment have to pass. The high containment facilities are not expected to become operational before the end of 1978 , in part because the German government has only just adopted its guidelines for recombinant DNA research. In the meantime staff are being specially trained and a committee is being established to assess priorities for use of the laboratories by visiting and staff scientists. Most of the latter have recently taken up residence at EMBL.

Still under discussion is the possibility of setting up courses in training in recombinant DNA techniques, and the question of the extent to which visiting scientists will be allowed to carry out their own experiments rather than entrust them to EMBL technicians. Despite some local antagonism to the laboratory ("The Monster in the City Woods", according to a Janurary issue of the student paper Heidelberger Rundschau), it is anticipated that P4 experiments will be smoothly under way within a year.

The EMBL does not have its own lecture theatre suitable for gatherings

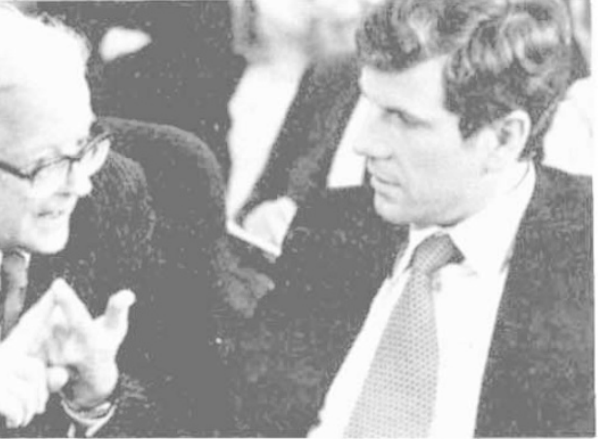

as large as the 200 people who attended the inauguration for which it made use of the facilities of the Max Planck Institute für Kernphysik (nuclear physics) next door. It does, however, have an ample canteen and a large library. It did not escape my attention that the longest complete run of a journal on display in the library was that of Nature. It seemed very fitting for the European Molecular Biology Laboratory that their Nature started with that 1953 volume which contained Watson and Crick's "A Structure For Deoxyribose Nucleic Acid."

The inauguration ceremony was attended by some 200 dignitaries including Dr Hauff, the Ministers of Research of Austria, France and Sweden and many eminent scientists who have acted or still serve as consultants, advisers or members of the Laboratory Council. Dr Hauff, who was a last minute replacement for Dr W. Scheel, President of West Germany, detained by the state visit of $\mathrm{Mr}$ Brezhnev, used the occasion to deliver a remarkably strong statement in support of the freedom of scientific investigation. Science, he said, was an integral part of the spiritual and intellectual freedom that was essential for the survival of a democratic state. The state should not pander to that group of sceptics among the educated strata who wished the state to intervene in the course of scientific investigation. Only when that course departed from the intellectual search for scientific truth to impose itself upon society did $\mathrm{Dr}$ Hauff believe that the state should consider setting limits. As an example of that he cited research on recombinant DNA. levels of the entire nation.

Attention was not to be confined to higher education, Teng said. The scientific content of both primary and secondary school curricula was to be increased. Furthermore, differences in academic ability were no longer to be covered up. Special training of the talented could be combined with broad educational opportunities and students treated differently, so long as the aim remained the creation of conditions for every individual to advance and not the suppression of some for the benefit of others.

Education as a whole was to keep pace with the needs of agriculture and industry, and state departments would work together to integrate the educational programme into the framework of the national economy. Finally, Teng said, the country's nine million teachers held the key to success. They should be respected by their pupils, while they themselves should continue to improve themselves politically and professionally, making full use of postexperience courses, new reference materials, modern teaching aids, radio and television.

Another significant development has been in the Kwangming Daily, one of the three national newspapers published in Peking, which since 1 May has devoted most of its issues to scientific and educational coverage.

And from the province of Anhwei comes the news that, of the 700 new students starting at the Chinese Scientific and Technological University, 92 are under 16. They are students who, with the help of friends and teachers, have progressed well beyond formal levels of education through self-study.

T. B. Tang

\section{Core curriculum}

$I_{N}$ a decision likely to have implications for university courses across the USA, the faculty of Harvard University voted last week to accept a new "core curriculum"-including a course in scientific methodology and an obligatory test of mathematical competence-to be taken by all undergraduates. 